\title{
Eliciting Substance from 'Hot Air' Financial Market Responses to EU Summit Decisions on European Defense
}

\section{Journal Article}

\section{Author(s):}

Bechtel, Michael M.; Schneider, Gerald

Publication date:

2010

Permanent link:

https://doi.org/10.3929/ethz-b-000018000

Rights / license:

In Copyright - Non-Commercial Use Permitted

Originally published in:

International Organization 64(2), https://doi.org/10.1017/S0020818310000019 


\title{
Eliciting Substance from 'Hot Air': \\ Financial Market Responses to \\ EU Summit Decisions on European \\ Defense
}

\author{
Michael M. Bechtel and Gerald Schneider
}

\begin{abstract}
The results of deliberations in multilateral fora are often considered ineffective. Decision making in the European Union (EU) and in particular its key intergovernmental body, the European Council, poses no exception. Especially in the domain of EU foreign and security affairs, the unanimity requirement governing this institution allegedly allows nationalist governments to torpedo any attempt to build up a credible European defense force and a unified foreign policy stance. In this article, we take issue with the claim that multilateral summits merely result in "hot air" by looking at whether and how decisions made during EU summit meetings affect the European defense industry. We argue that investors react positively to a successful strengthening of Europe's military component-a vital part of the intensified cooperation within the European Security and Defense Policy (ESDP) - since such decisions increase the demand for military products and raise the expected profits in the European defense industry. Our findings lend empirical support to the view that financial markets indeed evaluate the substance of European Council meetings and react positively to those summit decisions that consolidate EU military capabilities and the ESDP. Each of the substantial council decisions studied increased the value of the European defense sector by about 4 billion euros on average. This shows that multilateral decisions can have considerable economic and financial repercussions.
\end{abstract}

One of the most persistent prejudices among analysts of international relations is the view that decisions made at multilateral summits hardly affect markets in a significant way. This skepticism is nurtured by the realist perception that national interests prevent states from being able to agree on and credibly commit to lasting cooperation. This view seems particularly suited to multilateral decision making in the area of security and defense, which directly concerns states' primary objec-

We are extremely grateful to Fabio Franchino, Christopher Kilby, Vally Koubi, Vera Troeger, James Vreeland, Christoph Moser, and two anonymous referees for their excellent and insightful comments on earlier versions of this article. The usual disclaimer applies. 
tive of securing a maximum of political power and autarky. ${ }^{1}$ Such skepticism begs the question of why the international financial press continues to report extensively about multilateral summits. An obvious explanation is that the conventional wisdom on the ineffectiveness of international diplomacy and decision making is in need of qualification. This is especially the case in light of the emerging evidence that international political events systematically affect markets. ${ }^{2}$

In this article, we contribute to this emerging literature by looking at whether and how markets evaluate the outcomes of multilateral decision making. To this end we examine some of the financial repercussions of the intergovernmental summits of the European Union (EU). Our analysis focuses on the domain of foreign and security affairs - an area of cooperation for which some early observers never expected the European integration to encroach upon. ${ }^{3}$ Indeed, ever since the foundation of the EU and its predecessor organizations, defense and security issues have remained exempt from both supranational decision making and majority rule. This means that the main intergovernmental institution of the EU, the European Council, still makes all key decisions on such matters.

As this institution is not forced to publish an official agenda for these top-level summit meetings in advance, the European population is only indirectly able to assess their relative importance. Given the secrecy surrounding these summits and the need to make decisions by unanimity, it is not surprising that some observers perceive the results of the intergovernmental diplomacy as hot air and to be of little relevance to the real problems of the EU. Interviewed by the International Herald Tribune, Daniel Gros from the Center of European Policy Studies described these gatherings as "a waste of time." ${ }^{4}$ Indeed, it is widely acknowledged that decision making within the EU and particularly in the European Council is still byzantine and ineffective. ${ }^{5}$

We will examine whether the gatherings of the European Council only amount to hot air, as such statements imply. Although we do not believe that the general public observes the high-level EU summits closely, some investors and traders might watch these gatherings intensively because of the possible redistributive nature of the decisions by the council. This is especially true for those industries that heavily benefit from public contracts resulting from intergovernmental agreements. The European defense sector, an industry with annual sales worth more than 50 billion euros, constitutes a prime example, as it is almost completely dependent on government contracts.

The destiny of the European armaments industry has always been closely intertwined with the ups and downs of the integration project. To start with, politicians

1. See, for example, Mearsheimer 1990 and 1994; or Grieco 1988.

2. See Mauro, Sussman, and Yafeh 2006; Schneider and Troeger 2006; and Mosley 2004.

3. Hoffmann 1966.

4. International Herald Tribune, 26 October 2005. Available at 〈http://www.iht.com/articles/2005/ 10/26/news/summit.php $\rangle$, accessed 8 January 2010.

5. See, for example, Hix 2008. 
still continue to allude to the security motivations behind the EU. Admittedly, Milward $^{6}$ and others have demystified the origins of the integration process and especially its underlying political causes. Others have, as noted, warned that European integration will never advance to highly politicized areas such as foreign policy or security affairs. ${ }^{7}$ Yet, against this skeptical backdrop, the EU started in the 1990s to "Europeanize" the security policies of the member states through the development of common institutions, increased cooperation in defense and security matters, and the build up of military capabilities. The Maastricht Treaty already explicitly contained provisions regarding a common EU security and defense policy. ${ }^{8}$ The Treaty of Amsterdam (1997) added to this the "Petersberg tasks," with which the EU communicated its will to play a more active role in humanitarian and peacekeeping operations as well as tasks of combat forces in crisis management. For example, at the Helsinki summit (1999) European leaders agreed to create an EU-led intervention unit of up to 60,000 combat-ready soldiers by 2003. Later summits resulted in the European Security Strategy (Brussels, 2003) and the European Battlegroup Concept (Brussels, 2004). Some commentators described this process as "raising the flag for Europe's army." 9

We theorize in this article that decisions on the EU's military component are important for the performance of European defense firms, as they affect the order books of companies operating in the defense sector. Investors should therefore carefully evaluate the outcome of European Council meetings. In our view, some of these intergovernmental meetings are not a "waste of time," but rather provide crucial information about key economic decisions. In our case, these are the attempts to further strengthen military capabilities at the European level. Traders will therefore carefully have identified those council meetings that were concerned with the European Security and Defense Policy (ESDP) and that actually resulted in decisions to build up military capabilities and to strengthen the defense and security component of the EU. We consequently argue that investors only expect raising profits in the defense sector, which manifests itself in an improved stock market performance of this industry, if European leaders make decisions relevant to this politically dependent sector. Hence, investors who are trading defense stocks only care about sector-specific "good news" and not about meetings that merely produce "hot air."

These theoretical considerations lead us to expect that the so-called abnormal return, that is, the return to defense firms during a summit meeting that cannot be explained by movements in other financial assets, increases if EU summit decisions provide investors with information that they consider to be "good news" for the future profitability of the European defense industry. Such sector-specific effects of EU summit meetings have not been examined until now, and our analysis will

6. Milward 1992.

7. Hoffmann 1966.

8. Maastricht Treaty, Article J.4.

9. Financial Times, 10 December 1999, p. 21. 
show whether the slow but significant Europeanization of EU member states' defense policies has any important short-term economic repercussions.

Our results suggest that decisions made by European Council meetings indeed affect the European defense sector in a nuanced way. In line with our argument, summits that were associated with significant decisions to advance the ESDP triggered a significantly positive abnormal defense stock return even when we control for other potentially relevant factors for the European integration process, for example, national elections or referenda in key member states and preferences of the weightiest EU member states on EU integration. Moreover, investors seem to have carefully differentiated between summits that resulted in a push forward on Europe's military capabilities-increasing expectations about future defense-sector profitability - and those on which the ESDP was an issue but leaders did not agree on taking further steps to strengthen Europe's defense and security component. More generally, our results demonstrate that research on the political economy of European integration and the relevance of its institutions is likely to gain valuable insights from assessing the short-term economic effects of European politics. Moreover, our analysis shows that the often-derided summit meetings have considerable economic and financial repercussions in Europe and, by extension, most likely beyond this politically highly integrated continent.

\section{European Summits and the Defense Sector}

The European Council, which regularly brings together the heads of governments and, in the case of France and Poland, the heads of state, of the EU member states in the form of so called European summits, is still the key decision-making body within the EU. Given the lack of influence of the European Parliament and other supranational actors within the EU, this intergovernmental body determines singlehandedly the depth and scope of European cooperation and more generally the pace of the integration process. Political scientists have long debated the effectiveness of decision making in the European Council. This controversy originated from the observation that European integration is a rather discontinuous phenomenon. Undoubtedly, there were great steps toward increased integration with economic aspects playing a key role, as the promotion of the internal market or the creation of the European Monetary Union (EMU) show. On the other hand, not every summit meeting of the council results in such landmark treaties as the Single European Act of 1986 or the Maastricht treaty in 1992. Standard attempts to explain this variance in summit outcomes focus on spillover effects and the power of supranational institutions ${ }^{10}$ or the influence of domestic preferences of ${ }^{11}$ and the presence of information asymmetries between member state governments. ${ }^{12}$

10. Sandholz and Zysman 1989.

11. See Moravcsik 1993 and 1998.

12. Schneider and Cederman 1994 
Despite disagreement about the relative importance of the driving forces behind European integration, scholars generally share the view that the meetings of the European Council are key events for the process of European integration. One prominent approach, liberal intergovernmentalism, claims that national economic interests largely shape the intergovernmental treaty negotiations in the Council. ${ }^{13}$ Analyses of the other intergovernmental body, the Council of Ministers, which figures prominently in EU legislation, similarly point out that the divide between net beneficiaries and net contributors drives the deliberations among ministers of the member-state governments. ${ }^{14}$

The interrelatedness of the European economy and the political collaboration between the EU member states has so far mainly inspired researchers to uncover the economic sources of European integration or the long-term growth effects that key integrative decisions have brought about. ${ }^{15}$ Econometric studies in the latter domain have shown a significant impact of the internal market on economic growth. ${ }^{16}$ If the entire economy reacts in the long term in a foreseeable direction to political decisions, we should observe equivalent economic short-term reactions to key events within the EU.

However, studies that explore such short-term economic effects of European politics are very rare. The articles by Brady and Feinberg and Feinberg and Harper ${ }^{17}$ are notable exceptions. Brady and Feinberg find that announcements of progress toward stricter European merger rules as well as several other events associated with legislation on merger regulation had a substantial impact on the stock values of individual companies. Feinberg and Harper argue that especially the British banking sector was well prepared to take advantage of a regime change toward common European rules for market expansion. This would make it easier for businesses to benefit from the elimination of barriers to intra-EU mergers, which should increase their expected profits. Focusing on UK firms from the banking sector, their estimates show that between 1988 and 1990 events that suggested an increased probability that the EU would adopt the proposed European merger control regulation and the second banking directive caused positive abnormal returns. Thus, both studies show that specific supranational EU policy decisions indeed had shortterm repercussions.

In this application, we will examine the short-term economic effects of decisions made by one of the most important bodies of the EU, the European Council. We argue that the choices made by this intergovernmental body can have considerable economic repercussions in sectors where demand is heavily driven by (European) political decisions. Of course, the prime sector for such an analysis is the defense industry whose order books and thus profits crucially depend on orders

13. Moravcsik 1993 and 1998.

14. Zimmer, Schneider, and Dobbins 2005.

15. Moravcsik 1998.

16. See Baldwin, Chiappori, and Venables 1989; and Micco, Stein, and Ordoñez 2003.

17. See Brady and Feinberg 2000; and Feinberg and Harper 1999. 
by government agencies. We will therefore examine whether and how this sector reacts to the summit meetings for which the council convenes at least twice a year.

European Council Meetings, the ESDP, and European Defense-Sector Performance

Our focus on the European Council meetings is substantively justified, as the history of EU cooperation in defense and security policy and the buildup of military capabilities is still largely a history of European treaties and the negotiations about them. We argue that deals struck on issues of defense and the EU's military capabilities have become key events for the prosperity of European defense firms, as these are highly dependent on public demand for their products. This simple argument about the economic effect of summit decisions implies a nuanced causal mechanism: we theorize that investors carefully differentiate between summits that resulted in significant steps toward the buildup of a "European army" and those on which defense was an issue, but leaders did not reach an agreement that moved beyond what had already been common knowledge on the ESDP and EU's military capabilities.

There are several reasons for why European leaders find it attractive to cooperate in defense and security policies. First, in the early 1990s, governments realized that their defense forces, which were structured and equipped during the Cold War and therefore intended to protect national territory, were not well prepared to meet the demands of today's peace enforcement and peacekeeping operations. According to Whitney ${ }^{18}$ only 30 percent of land forces were able to operate outside the national territory. Second, governments can exploit synergy effects by avoiding duplication of military projects within the defense industry. ${ }^{19}$ Thirdly, by pooling their military resources and making their defense forces more effective, European leaders can increase their international bargaining power, including their political weight toward the United States. Since the field of defense policy is still intergovernmental and of high political salience, European Council meetings, which bring together the leaders of EU member countries, are the obvious arena for negotiating ESDP issues. Table 1 provides an overview of those council meetings that were associated with important decisions to increase ESDP cooperation and to build up military capabilities. ${ }^{20}$

The decisions mentioned above (and summarized in Table 1) resulted in what can be reasonably called significant steps in strengthening the military component of the EU. ${ }^{21}$ To illustrate the significance of European Council meetings for defense

18. Whitney $2008,1$.

19. See, for instance, Sandler and Hartley 1999, chap. 4.

20. These codings were checked by two experts in the field in order to increase intercoder reliability.

21. "EU defence agency approved," Financial Times, 15 June 2004, p. 8. 
TABLE 1. Strengthening the ESDP and Europe's military capabilities: EU Council meeting decisions 1993-2005

\begin{tabular}{|c|c|c|}
\hline Summit & Summit date & Outcome \\
\hline Amsterdam & 16 June 1997 & $\begin{array}{l}\text { Petersburg tasks; treaty signals the progressive framing of a } \\
\text { common security and defense policy based on the Petersberg } \\
\text { tasks. }\end{array}$ \\
\hline Cologne & 3 June 1999 & $\begin{array}{l}\text { Buildup of military capabilities; EU leaders agree that the } \\
\text { EU should have its own military capacity to tackle regional } \\
\text { crises in Europe, backed by sources of intelligence and } \\
\text { capabilities for analysis and strategic planning. }\end{array}$ \\
\hline Helsinki & 10 December 1999 & $\begin{array}{l}\text { Agreement on "European headline goal" specifying the need } \\
\text { for a rapid response capability, adding a security and defense } \\
\text { arm to the EU (capacity to have a corps of up to } 60,000 \text { men } \\
\text { on peacekeeping operations). }\end{array}$ \\
\hline Brussels & 12 December 2003 & $\begin{array}{l}\text { Summit approves the European security strategy ("A Secure } \\
\text { Europe In A Better World"), formulating for the first time a } \\
\text { common security strategy for Europe. }\end{array}$ \\
\hline Brussels & 17 June 2004 & $\begin{array}{l}\text { European Battlegroup (EUBG) Concept: EU military forces } \\
\text { under direct control of the European Council, each consisting } \\
\text { of approximately } 1,500 \text { combat-ready soldiers deployable } \\
\text { within fifteen days of approval from the European Council. }\end{array}$ \\
\hline
\end{tabular}

matters, the Cologne European Council (June 1999) can serve as an example. This summit focused on the Petersberg tasks and stated its willingness to set up the necessary military capabilities:

In pursuit of our Common Foreign and Security Policy, we are convinced that the Council should have the ability to take decisions on the full range of conflict prevention and crisis management tasks defined in the Treaty on European Union, the "Petersberg Tasks." To this end, the Union must have the capacity for autonomous action, backed up by credible military forces... ${ }^{22}$

Most importantly for our argument, the European Council underscores the need to strengthen its military capabilities and to more closely collaborate with the defense industry:

We therefore commit ourselves to further develop more effective European military capabilities from the basis of existing national, bi-national and multinational capabilities and to strengthen our own capabilities for that purpose... We also recognise the need to undertake sustained efforts to strengthen the industrial and technological defense base, which we want to be competi-

22. European Union 1999, Annex III, p. 27. 
tive and dynamic... With industry we will therefore work towards closer and more efficient defense industry collaboration. ${ }^{23}$

These aims were specified in more detail by the Helsinki European Council (December 1999) in that EU member states agreed on the so-called European headline goal: for EU-led operations, member states were required to be able to deploy military forces of up to 50,000-60,000 soldiers capable of the full range of Petersberg tasks within sixty days and sustain for at least one year. The European Council meeting in Brussels on 12 December 2003 agreed on a "European Security Strategy" in which member states point out that the EU should "develop a strategic culture that fosters early, rapid and when necessary, robust intervention" and needs "the full spectrum of instruments for crisis management and conflict prevention at our disposal, including political, diplomatic, military and civilian, trade and development activities." 24

Indeed, what initially began at the Amsterdam summit in 1997 has resulted in the buildup of so-called European battle groups (EUBG), the EU's rapid reaction force. The EUBGs reached full operational capability on 1 January 2007 and some conceive this as proof that "the European Union has quietly acquired what might be described as a standing army." ${ }^{25}$ Thus, ESDP decisions by the European Council seem to have been of considerable substance in light of these policy outcomes, and we argue that these summits had positive consequences for the profitability of European defense firms.

Looking at all council meetings, however, shows that there is variance in these ESDP choices. Although the ESDP and especially Europe's military capabilities played a role during other council meetings as well, these summits were far less successful in instigating further cooperation in this policy sector. For example, during the Göteborg European Council (June 2001) member states merely repeated what had been agreed on already, namely that "the European Union is committed to developing and refining its capabilities, structures and procedures in order to improve its ability to undertake the full range of conflict prevention and crisis management tasks." ${ }^{26}$ Also, the Laeken summit (December 2001) and the Treaty of Nice (2000) only emphasized the importance of enhancing the EU's military

\section{Ibid., 28.}

24. European Union 2003, 11.

25. Anecdotal evidence about the lobbying behavior of defense firms underscores the idea that summit decisions that increased ESDP cooperation and strengthened the military arm of the EU benefited the European defense industry. For example, when the European Defence Agency (EDA), whose aim is to improve the EU's military capabilities, was approved by EU member states in 2004, Europe's three largest defense firms officially welcomed the creation of the body. They also took the opportunity to emphasize that "only through consolidating spending and research budgets can EU countries compete with rapidly expanding U.S. defense budgets" and urged the EU "to have the new body identify holes in capability and push member states to increase funding to fill the shortfalls." BBC, "New force behind EU foreign policy," 15 March 2007. Available at 〈http://news.bbc.co.uk/1/hi/ world/europe/6441417.stm >, accessed 8 January 2010.

26. European Union 2001: V: 11. 
operational capabilities as a part of developing the European security and defense policy, which had been presented already by the Cologne summit in 1999. Finally, many council meetings did not even touch issues of the ESDP and questions of the EU's military capabilities.

We argue that investors carefully differentiate between the differing outcomes of these summits: meetings that result in significant steps toward the buildup of a common ESDP and the creation of an "European army" should increase investors" expectations about future profits of the European defense industry ("good summits"). In contrast, summits that do not discuss the ESDP ("irrelevant summits") or merely repeat existing decisions without reaching an agreement that moves beyond what already is common knowledge ("bad summits") should not bolster investors' expectations. More precisely, there should be no "agenda effect," that is, merely putting ESDP issues on the agenda should not affect investors' expectations about future performance of the European defense sector. As we subsequently elaborate, our theoretical framework has straightforward empirical implications we can evaluate using stock market reactions to summit meetings.

\section{Summits and Stocks: Using Stock Market Reactions to Estimate the Short-Term Economic Effects of ESDP Decisions}

We have argued about the impact of ESDP decisions by the European Council on the future performance of the European defense industry. More precisely, we theorize that if a summit meeting results in an agreement that strengthens defense policy, such an outcome raises the expected profitability of the European defense sector due to an increase in the expected demand for military products. How can we empirically evaluate whether this theoretical reasoning has explanatory power? Our evaluation strategy follows a growing body of literature that exploits stock market reactions to political events in order to learn about the economic effect of politics on firms or sectors. ${ }^{27}$ On stock markets, investors react to events only if these provide information that leads to an updating of their beliefs about the expected profitability of an asset. Consequently, return reactions to events can be used to uncover their economic effects, that is, the economic winners and losers of political decisions.

Clearly, the profitability of the European defense sector is strongly politically determined (defense firms rarely sell their products to private actors). Based on this assumption about the strong dependence of the defense sector on public demand, any change in the political information available to investors will induce a change in the expected value of a defense stock investment through a change in the expected profitability of the European defense sector. If the expected value increases, investors will invest more in European defense stocks, leading to higher 
demand and thus to a higher price of defense stocks. If the expected value decreases, investors will reallocate their capital accordingly, that is, pull money out of the European defense sector. This decrease in demand for defense stocks of course leads to a lower stock price. Therefore, as we expect a positive relationship between EU summit outcomes that aim at strengthening the EU's military capabilities and the profitability of the European defense industry, stock returns to European defense firms should react positively to such "good summits."

Hypothesis: Summits outcomes that strengthen the ESDP lead to an increase in the return on defense stocks.

A rival explanation for the effect of summit decisions on defense-sector returns' relative performance might be that these are driven by summit outcomes that are of general importance to European financial markets, that is, if EU leaders reach agreements that are considered to be economically important more broadly in contrast to narrow decisions concerning the ESDP and the build up of EU military capabilities. In the empirical estimation we will carefully test our argument against rival and along with complementary explanations.

Our evaluation strategy to some extent follows the idea of a quasi-experiment and involves two steps. The first step consists of generating a synthetic defense return series (control group) which we compare with observed defense return performance around European summit meetings. This yields the so-called abnormal return. Second, we explain differences in the abnormal return reactions to summit decisions by their content: meetings that merely discussed ESDP issues should be inconsequential for abnormal defense returns while summits that resulted in closer ESDP cooperation should have a positive effect on abnormal return performance.

\section{Data and Method}

We compiled a dataset comprising daily stock prices of seven major European defense firms from 1993 to 2005 whose stocks were publicly listed. Table 2 shows which companies are included in our sample along with their main products. To gain an impression of the economic importance of the European defense industry, note that these firms generated about 53 billion euros turnover (annual gross income) and employed more than 167,000 individuals in 2004. Daily stock prices were available from 1993 to 2005 for most firms (BAE Systems, Chemring Group, Finmeccanica, Thales, and VT Group) except for EADS (starting in July 2000) and Ultra Electronics (starting in October 1996).

As one would expect, unit root tests clearly suggest that the stock price series are nonstationary, which means that these variables cannot be used for consistent estimation. We log-differenced the raw price series to obtain continuously compounded returns that we needed also for theoretical reasons since our interest lies 
TABLE 2. European defense firms

\begin{tabular}{|c|c|c|}
\hline Defense firms & Main products & Turnover/employees (2004) \\
\hline
\end{tabular}

BAE Systems $\quad$ Combat aircrafts; armored combat 12 billion $€ ; 19,000$ employees vehicles; major and minor caliber naval guns; missile launchers; artillery systems; intelligent munitions; submarines; naval ships; electronic warfare systems; military air support; and air defense

Chemring Group Countermeasure products: expendable decoys/obscurants against radar, infrared, and electro-optically directed weapons; pyrotechnics; pyro-mechanisms; medium and large-calibre ammunition; rocket motors; gas generators; initiators; and actuators

EADS Military transport aircrafts; helicopters (reconnaissance, observation, fire support, protection combat mission); and airborne ground surveillance

Finmeccanica Helicopters; missile systems; torpedoes; naval artillery and armored vehicles; and military communications

Thales $\quad$ Air defense command and control systems; systems for surveillance, reconnaissance, and combat; and vehicle and soldier systems

Ultra Electronics Military radios; submarine communications equipment; cryptographic equipment; armored vehicle systems; combat system for minor warships; and naval power systems

VT Group Naval ships; military transmission and communications infrastructure; asset management of naval ships; and military aircraft and vehicles

140 million $€ ; 42,537$ employees

30.1 billion $€ ; 111,000$ employees

11 billion $€$; 56,600 employees

10.3 billion €; 20,000 employees

392 million €; 2,673 employees

850 million $€ ; 8,683$ employees

Notes: Information taken from firms' websites. Turnover and employee figures taken from firms' publicly available profit and loss statements.

in evaluating the return reactions to EU summits. Results from nonparametric Phillips-Perron unit root tests indicate that the returns are stationary. ${ }^{28}$

\section{An Event Study Approach}

We conduct an event study to uncover the economic dependence of European defense firms from ESDP decisions during EU summits. Event studies are com-

28. Appendix Table A1 is available at 〈www.ib.ethz.ch/people/mbechtel〉, accessed 2 February 2010. 
mon in financial economics, where they have been used to study the economic effects of a wide range of political phenomena that affect shareholder wealth through their impact on firm and industry performance. In the political economy literature, this method has been applied to estimate the wealth effects of holding a seat in the U.S. Senate or the value of political connections to the Suharto regime. ${ }^{29}$ More recent applications use event study methods to assess the economic effects of violent conflict. ${ }^{30}$

A noteworthy objection against event studies is that efficient markets should anticipate political events, and therefore any significant correlations with political variables are either spurious or evidence for markets not processing information efficiently. However, this argument misses the fact that in a world of uncertainty, political events are almost never perfectly predictable. This is all the more plausible in our case for at least two reasons. First, the precise agenda of European Council meetings is frequently unknown beforehand. Investors therefore have a hard time predicting the agenda and can hardly anticipate the final outcome. Second, while EU summits have sometimes produced significant policy changes and pushed European integration, they have often failed to achieve clear steps toward integrationist policy. This stop-and-go pattern makes prediction of council outcomes a difficult task, even if economic actors update their beliefs in a rational manner (and even if the precise summit agenda were known beforehand).

Third, making predictions about outcomes on council decisions is complicated by the existence of information asymmetries between member states' governments and their incentive to engage in threats and bluffs. ${ }^{31}$ Therefore, it is reasonable to assume that even efficient markets cannot perfectly predict council decisions. Consequently, our estimates of stock market reactions to council meetings are more likely to yield accurate results, which are not confounded by anticipation effects. ${ }^{32}$

Since the changes in returns contain information about the changes in expected value of the underlying asset, we define the daily return $R_{t}$ at time $t$ as $R_{t} \equiv \ln S_{t}$ $-\ln S_{t-1}$, where $S_{t}$ denotes the stock price at $t$. Let $E\left[R_{f, t} \mid x_{t}\right]$ be the expected (or normal) return of firm $f$ conditional on a set of covariates $x_{t}$. The normal return is the return we would expect in the absence of the council meeting. Thus, the normal return is the counterfactual we compare with observed return performance. Formally, the abnormal return $A R_{f, t}$ is defined as

$$
A R_{f, t} \equiv R_{f, t}-E\left[R_{f, t} \mid x_{t}\right]
$$

29. See Ziobrowski et al. 2004; and Fisman 2001.

30. See Schneider and Troeger 2006; and Guidolin and La Ferrara 2005 and 2007.

31. Schneider and Cederman 1994.

32. Clearly, anticipation might nonetheless occur. But even then our estimates reflect short-term reactions to European Council meetings, although they might capture only a part of the effects council meetings exert on defense firms. This means that our approach is conservative as it is likely that the true effect is underestimated. 
In words, the abnormal return is the difference between the observed return and a control series of synthetic returns representing the return we would expect in the absence of a summit meeting given the covariates $x_{i}$.

An important task is to determine the normal return, that is, the return we would expect if no summit took place. To generate our control series of synthetic returns we employ a model based on asset pricing theory (APT). ${ }^{33}$ The APT starts from a simple yet powerful idea: in equilibrium two assets that are different cannot be sold at the same prices. This is to say that in the world of the APT, assets adhere to the law of one price, since investors will immediately take advantage of any arbitrage opportunity. ${ }^{34}$

Based on the APT, we model the synthetic control return as a linear function of the returns on other assets. More formally, normal performance is given by

$$
R_{f, t}=a+\sum_{j=1}^{J} b_{j} R_{j, t},
$$

where $a$ is a constant, $R_{f, t}$ is the return to risky asset $j$ at time $t$, and the $b_{j}$ terms (also called weights) reflect how changes in the return to asset $j$ translate into changes in the defense return $R_{f, t}$. As investors will not leave any opportunity to profit from arbitrage unexploited, selecting a subset of risky assets into the APT model is sufficient to determine normal performance. Still, the APT can be considered a more conservative version of the simple Capital Asset Pricing Model (CAPM) in the sense that more assets are used to estimate normal performance than just the market return. In our case, the return to a general European stock market index, the U.S. stock market return (Dow Jones), Oil return, and the eurodollar exchange rate were chosen to estimate the weights. Results from PhillipsPerron tests show that these return series are stationary.

Many summits take place on weekends. But investors cannot rebalance their portfolios on Saturday or Sunday, and therefore, new information released during the meeting cannot be incorporated into current prices. Past research on politically induced abnormal returns has tried to circumvent this problem by interpolating returns in order to fill in missing values on nontrading days. However, this procedure is unlikely to adequately substitute for missing return observations. Instead, we opt for shifting events occurring on nontrading days to the next trading day, when investors are in fact given the opportunity to trade on the basis of the latest information released during or immediately after a summit meeting and therefore, in accordance with their updated beliefs.

To generate the synthetic return series that represents normal performance, we add an error term with a mean of zero and constant variance to equation (2) and

33. See Elton et al. 2007, 362 .

34. This assumes that investors have homogenous expectations and hold well-diversified portfolios. 
estimate this equation within a $[-q,-20]$-estimation window, where $q$ is set such that the distance between the previous summit and the subsequent estimation window of the following summit is at least ten days. While this ensures that there is no overlap between the event or estimation window of the previous summit, a consequence is that we are left with thirty-six out of thirty-nine summit meetings, because we have to drop the Luxembourg summit (12 December 1997), a council meeting in Copenhagen (12 December 2002), and a summit in Brussels (20 March 2003) from our analysis. However, this is advisable because it prevents the parameters from being confounded by event-induced return effects. The weights are estimated on the basis of return observations $q$ to twenty days (that is, four trading weeks) prior to an European Council meeting. ${ }^{35}$

Based on the synthetic return series computed from the APT weights, we compute two standard quantities that are useful for the empirical analysis: (I) the abnormal return $A R_{f, t}$ to defense firm $f$ on day $t$, and (II) the average abnormal return $A A R_{t}$, which is simply the mean return to defense firms at time $t$. Thus, the average abnormal return provides information about the relative return performance of the whole European defense sector while the abnormal return represents how the stock return on each individual European defense firm performed relative to the APT benchmark.

\section{Key Variables}

We created several variables in order to evaluate whether there is empirical support for our argument about the conditional relevance of summit meeting decisions for the European defense industry. Probably the cleanest way to test our argument is to compare defense return reactions to summit meetings that put defense issues on the agenda but then failed to reach stronger ESDP cooperation with those that indeed strengthened the EU's military capabilities. DEF AGENDA is an indicator variable taking on the value 1 if the Financial Times (London edition) reported that the council meeting will discuss issues related to the European Security and Defense Policy and equals 0 otherwise. ${ }^{36}$ The use of information provided by the

35. The reason for letting the estimation window stop long enough before a summit occurs is that we have to prevent our estimates from being confounded by anticipation effects, for example, due to information leaks. This is not just a theoretical concern. Politicians often publish information about summit topics and likely outcomes immediately prior to European Council meetings. For example, before the Lisbon summit in March 2000, then European Commission president Romani Prodi informed the public about European Union leaders having already reached agreement on creating an integrated EU venture capital market and fully integrated financial services markets in 2005. See "Prodi delivers upbeat message ahead of EU summit in Lisbon," Financial Times, 22 March 2000, p. 1.

36. To generate this variable we performed a content analysis of the Financial Times (London ed.) using the LexisNexis database. We proceeded in two steps. First, we performed a search for the keyword "summit" within the Financial Times in the week preceding the first summit day and manually identified those dealing with EU summit meetings. Second, within this subset of articles we performed a keyword search for "defense" or "defence" or "security" and then manually identified those that informed readers that the ESDP was likely to play a role during the upcoming meeting of the Euro- 
Financial Times to generate this variable is justified, as it can be considered the most relevant newspaper for investors interested in European financial markets. ${ }^{37}$

The variable DEF GOOD NEWs is central to our study of the economic effects EU summit decisions on the European defense industry. It equals 1 if the council meetings resulted in increased ESDP cooperation and is 0 otherwise. More precisely, the results of the summit meetings summarized in Table 1 are coded as providing "good news." Given our theoretical argument, we expect that this variable has a significantly positive effect on abnormal returns of the European defense industry, while the coefficient for the variable DEF AGENDA should not be positive, that is, either be indistinguishable from zero or significantly smaller than zero.

\section{Control Variables}

Another explanation for the effect of European summit decisions on defensesector returns' relative performance might be that these are driven by council outcomes that are of general importance to European financial markets. EU leaders could reach agreements that are considered to be economically important more generally in contrast to narrow decisions concerning the ESDP and the build up of EU military capabilities. Since the defense sector is a particularly politicized industry, it might be that it also responds to European Council meetings in general. Thus, although we already account for general market movements by selecting several European financial assets into the APT model used to generate synthetic control returns, the defense industry could still be more sensitive to general economic decision made during council meetings than the overall market. This is to say that we should account for summits that are important to the financial community in a more general way.

To that end, we again performed a content analysis of the Financial Times during and after EU summits and created two variables intended to proxy for the extent to which a council meeting is important to financial actors in a general, defense-unrelated way. The rationale for using articles in the Financial Times is that this newspaper faces strong incentives to report more intensively about an EU summit the more important the meeting is to financial markets. The variable

pean Council. In addition, we checked that there were no other major events related to defense or security issues which occurred during EU summits, as this could lead us to wrongly attribute effects to council meetings. From 1993 to 2005, there were no other major international events taking place during summit meetings that one could arguably view to be relevant for the stock performance of European defense firms.

37. Initially, we thought about distinguishing expectations according to whether investors expected a strengthening or weakening of EU military and defense cooperation. However, one of the findings from our content analysis in the Financial Times is that there never was a case in which Financial Times commentators made explicit predictions about what outcome one should expect from a European Council meeting in terms of ESDP changes. Apart from the fact that this finding underscores our impression that summit outcomes are inherently difficult to predict, there was no sound basis for further distinguishing expectations about summit outcomes with regard to the ESDP decisions. 
SUMMIT INFO BEF counts the number of articles published before a council meeting that dealt with the upcoming summit. SUMMIT INFO AFTER is the number of articles published after a summit meeting took place.

The EU is a multilevel political system. This fact requires us to account for two major national political factors that may affect the stock market performance of the defense sector during or after an European Council meeting: elections and referenda. These partial foundations of the European defense sector in national politics can be deduced from the well developed literatures on the "two-level" nature of international decision making and democratic responsiveness to public opinion. ${ }^{38}$ Contributions to these research areas suggest that elections raise the hurdles for achieving integrationist decisions on summit meetings. ${ }^{39}$

Elections then function as a short-term corrective device: in order to appeal to their domestic electoral principals in the shadow of an election, political leaders slow down the pace of European integration. This is to say that in cases where a summit takes place immediately before a national election, investors attach a lower probability to the event that leaders agree on progressive integrationist steps that strengthen the EU's military capabilities. A relatively similar logic applies to summits that take place prior to a referendum. The literature on direct democracy within the EU argues that domestic ratification procedures raise the hurdles for achieving policy change. ${ }^{40}$ Therefore, simple strategic reasoning suggests that by way of anticipation, immediately prior to a national referendum investors should not expect leaders to agree on summit decisions that deepen integration in such a politically sensitive field as military affairs. To account for these factors, we created the indicator variable ELECTION that equals 1 if an election is scheduled in one of the three major member states of France, Great Britain, or Germany, and 0 otherwise. A second indicator variable (REFERENDUM) discriminates between summits that took place in the shadow of a scheduled EU referendum and those that did not.

The literature on decision making in the European Council suggests that the predictability of decisions made during summit meetings should also depend on the preferences of key member states regarding European integration. ${ }^{41}$ The more key member states are in favor of strong integrationist steps, the more investors can expect a summit meeting to result in significant ESDP changes from which the defense-sector benefits. The variable EU INTEGRATION uses data from the Comparative Manifestos Project (CMP) as a measure of governments' ideal point regarding more or less integration (higher values indicate a preference for more

38. See Hug and Schulz 2007; Aarts and van der Kolk 2006; Hug 2002; Powell 2004; Putnam 1988; and Schelling 1960.

39. There is a distinct gap between ideal policies of voters and parties. Regarding the European dimension, party elites are generally more in favor of integration than their electoral supporters (Mattila and Raunio 2006).

40. See Hug and Schulz 2007; Brouard and Tiberj 2006; and Schneider and Weitsman 1996.

41. See König and Pöter 2001; Schneider and Cederman 1994; Moravcsik 1993; and Bulmer and Wessels 1987. 
integration). ${ }^{42}$ One might argue that the EU dimension is inappropriate when it comes to questions of defense policy. Since defense issues lie at the heart of conservative politics, it is the classical left-right dimension that determines whether a government is in favor of building up a strong military component on the European level. We will address this concern in the robustness section.

Several additional control variables were created to account for influences from other factors. First, the predictability of summit decisions, and in turn the effect of summit meetings on European defense return performance, may also be affected by the European level of defense expenditure. For example, DiPietro and colleagues ${ }^{43}$ show that in the United States and the United Kingdom, military expenditures and stock market returns are correlated. Also, expectations about future defense spending levels may influence how defense returns react to European Council meetings. Nikolaidou ${ }^{44}$ estimates autoregressive distributed lag models for fifteen EU member countries and finds an extremely high degree of persistence in defense spending behavior, that is, current spending behavior is a very good predictor of future defense expenditure. In order to proxy for expectations, DEFENSE EXP measures average defense spending in France, Germany, Great Britain, and Italy in billion euros per year. ${ }^{45}$ One might also argue that it makes a difference whether a summit is extraordinary or not. To address this concern, EXTRA SUMMIT indicates whether a council meeting has this specific nature or not.

Since our data is time series cross-section, we need to decide whether to use a fixed or a random effects model. For each model, we used the Hausman test to asses whether (more efficient) random effects estimates significantly differ from those of a (consistent) fixed effects model. According to the results, there is no systematic difference between the coefficients from fixed and random effects models. Therefore, random effects, which offer higher efficiency, can be used without running the danger of relying on biased results. ${ }^{46}$

\section{Results}

In order to examine the economic repercussions of European Council decisions, we analyze the reaction of defense returns to summit meetings. We regress average abnormal defense returns (I) from a [-1,5]-event window on a reduced (reduced model) and a full (full model) set of explanatory variables. Our measures of EU key member governments are added in the full model to see whether the results remain robust. Since graphs help to more efficiently communicate our results along with measures of uncertainty, we follow Kastellec's and Leoni's recommendation

42. In the CMP data set the variable "PER108" measures preferences toward EU integration.

43. DiPietro, Anoruo, and Sawhney 2008.

44. Nikolaidou 2008.

45. The data was taken from the web pages of the Stockholm International Peace Research Institute.

46. The results for our key variable of interest remains unchanged if we use a fixed effects model. 
and present our regression estimates graphically. ${ }^{47}$ Figure 1 shows the results. The dots represent generalized least squares (GLS) point estimates and the horizontal lines indicate 90 percent confidence intervals computed from Huber and White (heteroskedasticity robust) standard errors.

Graphs by model

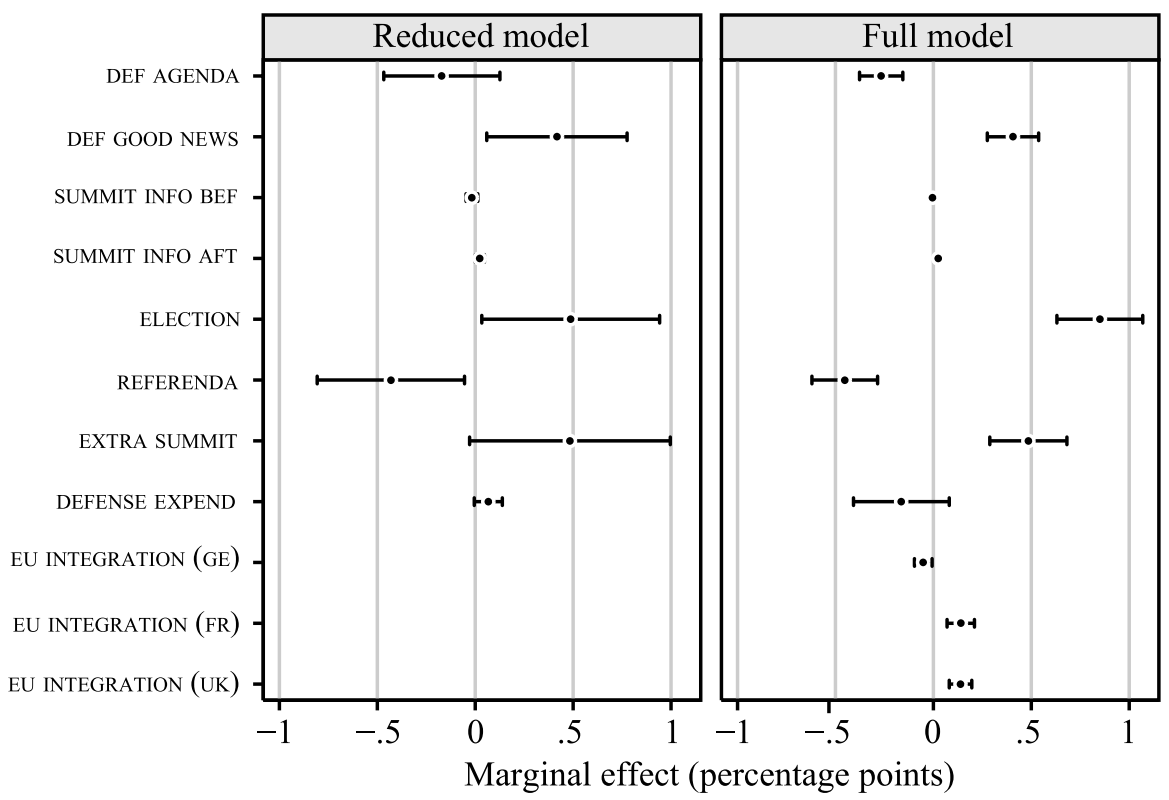

Note: GLS point estimates (with random effects) shown together with 90 percent confidence intervals computed from Huber/White (heteroskedasticity robust) standard errors. Constant included but not reported. For reduced model, $\mathrm{R}^{2}=0.07$; probability $=0.05 ; \mathrm{N}=1554$. For full model, $\mathrm{R}^{2}=0.08 ;$ probability $=0.00 ; \mathrm{N}=1554$.

FIGURE 1. Regressions of average abnormal defense returns $(A A R(-1.5))$ during EU sumits, 1993-2005

Does it matter for defense-sector performance if European leaders put the ESDP on the agenda of a summit? The results for the full model (Figure 2) suggest that these summits have a negative effect, while in the reduced model the coefficient on DEF AGENDA is not significant. Of course, this is compatible with what one would expect given our theoretical reasoning that predicts that summit outcomes matter: only summits that result in increased defense policy cooperation should be 
beneficial for the order books of European defense industry and thus their profits. Consequently, only these summits should trigger an increase in the relative return performance of the defense sector.

As shown in Figure 1, the empirical evidence supports this argument: the coefficient for the variable DEF GOOD NEWS is significantly greater than 0 . The point estimate suggests that strengthening ESDP cooperation significantly increases average abnormal defense-sector returns by about 0.4 percentage points. At first glance, the size of the effect seems moderate. Yet, this intuition is misleading. To gain an impression of the monetary dimension of this estimate, we collected data on the market capitalization of the European defense sector. This data is available from 1997 to 2005. Based on this information and using a 90 percent confidence interval, we can say that a 0.4 percentage point change in sector returns equals a change of about $4( \pm 0.5)$ billion euros in market value. Thus, even seemingly small return reactions may represent considerable wealth effects.

The point estimates for the summit information variables (SUMMIT INFO BEF and SUMMIT INFO AFT) are extremely close to zero, yet with very small confidence intervals. This suggests that even if council meetings that achieve agreements important to the European financial community in general affect the defense sector differentially, this effect is much smaller than that of summit meetings that strengthen ESDP cooperation.

According to the results from our fully specified model, elections also seem to matter: summits taking place in the shadow of a national election increase abnormal defense-sector returns. We believe that that this is largely a consequence of the fact that in the three countries included here either the EU was not a major topic at the time under examination or that the outcome of the election could relatively easily be anticipated. The latter explanation is all the more plausible, since the availability of polling data enables investors to form expectations about the likely outcome of an election.

\section{Robustness}

As a first robustness test, we re-estimated the models only using event time one observations, that is, average abnormal returns for the day directly following the end of a summit. This results in a sharp drop in the number of observations from 1,554 to 222. Our key finding remains unchanged. Summits that strengthen the ESDP are, on average, still associated with a 0.4 percentage point increase in average abnormal defense returns.

Our analysis so far has been at the industry level. Do the results remain robust if we further disaggregate the data and analyze the return performance of individual European defense companies? Figure 2 allows us to answer this question. First note that the coefficient for DEF AGENDA is negative and not significantly different from 0 . Thus, according to the firm-level results, council meetings that merely produce "hot air" with regard to the ESDP do not lead investors to expect Euro- 
pean defense firms to be more or less profitable on average. Most importantly, the estimates again suggest that summits during which European leaders agree on strengthening ESDP cooperation significantly increase the return performance of the individual European defense firms. According to the fully specified model, "good news" summits increase defense firms' abnormal returns by about 0.4 percentage points on average. This lends support to the view that investors carefully evaluate the consequences of EU summit decisions for the profitability of European defense firms, leading to the differences in how substantial decisions made during council meetings impact abnormal defense returns.

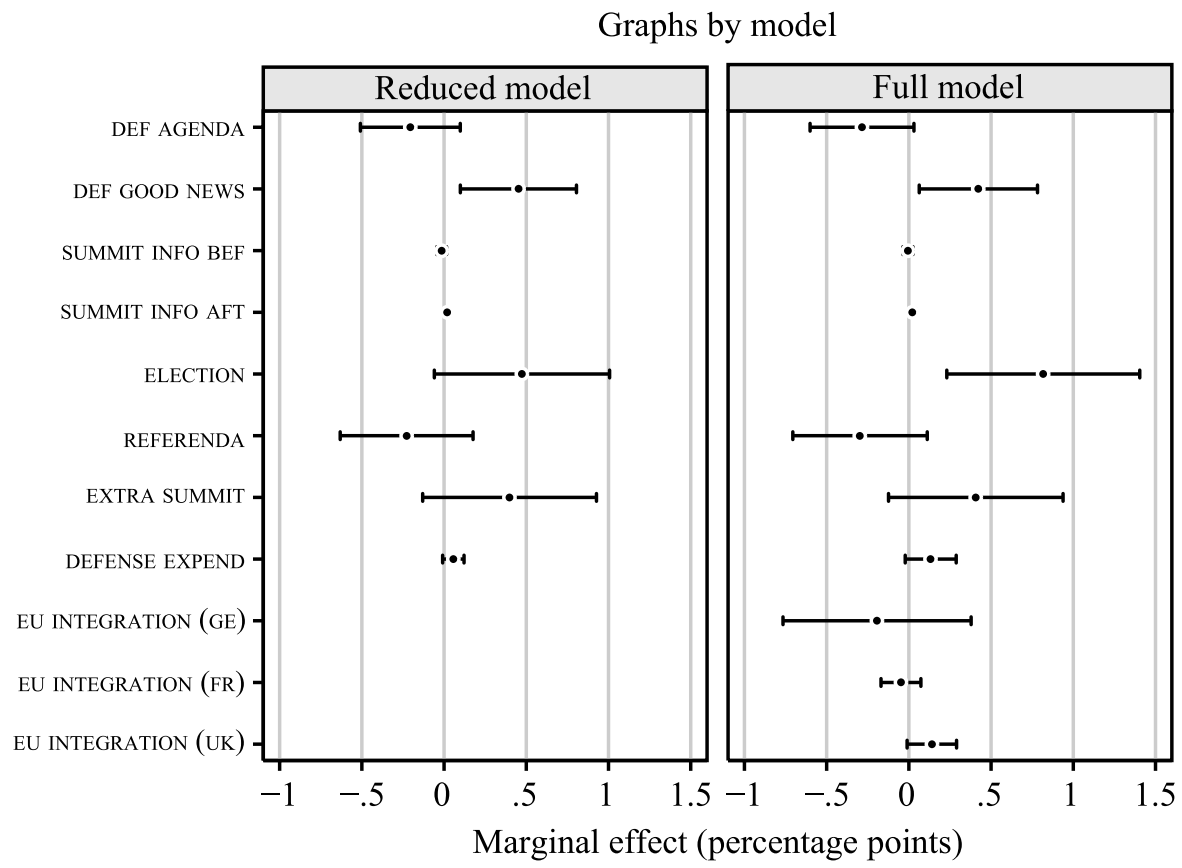

Note: GLS point estimates (with random effects) shown together with 90 percent confidence intervals computed from Huber/White (heteroskedasticity robust) standard errors. For reduced model, $\mathrm{R}^{2}=0.01 ;$ probability $=0.05 ; \mathrm{N}=1554$. For full model, $\mathrm{R}^{2}=0.01$; probability $=0.01 ; \mathrm{N}=1554$

FIGURE 2. Regressions of abnormal defense returns $(A R[-1.5])$ during $E U$ summits, 1993-2005

Obviously, at the level of the individual firm elections also play a role for the European defense sector, as the significant point estimate indicates. Summits that take place in the shadow of a national election increase the relative return performance of individual defense firms. Referenda do not seem to exert a significant 
effect. This finding might be due to differences in the information available to investors about these different types of political events. In particular, not only may EU issues have been neglected in national election campaigns, investors also are more likely to have more experience in forming expectations about the likely outcome of an election, but not (yet) in predicting referenda.

To further examine the robustness of the results, we re-estimated the effect of summit outcomes on abnormal defense and average abnormal defense returns varying the operationalization of our government ideal point measures. One might argue that in the case of defense policy, it is the ideological position of a government on a left-right scale that matters and not its stance toward European integration. Therefore, we re-estimated all models using two different measures of left-right ideology instead of preferences for European integration. ${ }^{48}$ The first measure was again taken from the CMP data. The second measure is the so-called Schmidt index as contained in the comparative political data set $1960-2005 .^{49}$ This five-point scale measure (GOVPARTY) distinguishes between ideologically different cabinet compositions and ranges from "hegemony of right-wing (and center) parties" (1) to "hegemony of social-democratic and other left parties" (5). The coefficient of the summit outcome variable (DEF GOOD NEWs) remains positive and statistically significant. Thus, summits that are associated with increased defense and military cooperation induce higher abnormal defense returns. In Models 3 and $4,{ }^{50}$ we repeat the estimations with average abnormal defense returns as our dependent variable. "Good summits" are associated with an increase in the relative return performance of the defense industry of about 0.4 percentage points on average. Therefore, our substantial conclusions remain the same.

\section{Conclusion}

The destiny of the European defense sector has always been closely related to the history of European cooperation. In the past years, the EU has strongly increased collaboration in defense and security policy and has built up its military capabilities; this development contradicts the view that the process of European cooperation is unlikely to encroach on defense policymaking. Some commentators described this remarkable and still relatively unnoticed trend as "raising the flag for Europe's army." 51 Defense issues frequently play a central role during European Council meetings with summit outcomes being difficult to predict while at the same time they are crucial to defense companies as these highly depend on public demand for their products.

48. See Appendix Table A2, Models 1 and 2, available at 〈www.ib.ethz.ch/people/mbechtel $\rangle$, accessed 2 February 2010.

49. See Schmidt 1992; and Armingeon et al. 2008.

50. See Appendix, available at 〈www.ib.ethz.ch/people/mbechtel〉, accessed 2 February 2010.

51. Financial Times, 10 December 1999, p. 21. 
Hitherto, the connection between multilateral decisions and the economy has only garnered limited academic interest. Scholarly attention has been devoted to the economic sources of European integration and the long-term growth effects that key integrative decisions have brought about. ${ }^{52}$ We exploit return reactions of defense stocks to European summits to estimate the effect of intergovernmental decision making on the European defense industry and the extent to which investors discriminate between the content of summit outcomes. Such an evaluation of the short-term economic consequences of multilateral decisions on an economically and politically important sector can help us understand the significance of the increased cooperation in the realm of European security and contribute to our knowledge about the relationship between international diplomacy and markets in general. Thereby, we add to an emerging literature on the interplay between institutions, political information, and markets.

We argue that since European defense firms' order books are almost exclusively a function of politically determined demand, investors should carefully evaluate the outcome of European Council meetings. Therefore, stock market reactions to European summits should be conditional on their outcomes: only if European leaders agree to deepen cooperation in ESDP, expected profits to the defense industry should increase, which the stock market will reflect with an increase in the relative return performance of defense stocks. In contrast, summits that merely put ESDP issues on their agenda should not increase the return performance of the European defense sector.

Our results suggest that decisions made during EU summits are indeed potentially important for defense-sector performance. We find empirical support for defense return reactions to summit meetings being conditional on their outcomes. Only council meetings that result in deeper ESDP cooperation trigger positive abnormal returns worth about $4( \pm 0.5)$ billion euros on average. This finding clearly contradicts the view that council meetings are just "talk shops" that lack any informational value and therefore are ignored by financial markets. Rather, it seems that investors in financial markets consider EU summit decisions and most likely other major diplomatic events to matter if the summit addresses key concerns of a particular industry. If summits produce results relevant for the market, traders carefully evaluate the outcomes of these meetings.

More generally, our findings demonstrate that multilateral decision making may be closely watched by investors and can have substantial short-term economic effects. This is not to say that the skeptical view many hold about the effectiveness of international institutions, diplomacy, and their relevance for the economy is incorrect. Yet, the potential for effective decision making within international institutions that is relevant for markets may be underestimated because we lack systematic evidence on when and how it matters. Our study constitutes a first step toward learning more about these phenomena and at the same time encourages

52. See, for example, Moravcsik 1998. 
future research to further examine the economic effects of international diplomacy. Finally, our research suggests that economically crucial events may be detected by studying the way in which financial markets differentiate in the short run between events that are important to them and those that will remain "hot air." Therefore, we are confident that research that evaluates short-term economic effects will also be valuable to those interested in unraveling which international political decisions shape the economy in the long run.

\section{References}

Aarts, Kees, and Henk van der Kolk. 2006. Understanding the Dutch No: The Euro, the East, and the Elite. Political Science \& Politics 29 (2):243-46.

Abadie, Alberto, and Javier Gardeazabal. 2003. The Economic Costs of Conflict: A Case Study of the Basque Country. American Economic Review 93 (1):113-32.

Armingeon, Klaus, Marlène Gerber, Philipp Leimgruber, Michelle Beyeler, and Sarah Menegale. 2008. Comparative Political Data Set 1960-2005, Institute of Political Science, University of Berne, Switzerland.

Baldwin, Richard, Pierre-Andre Chiappori, and Anthony Venables. 1989. The Growth Effects of 1992. Economic Policy 9 (3):247-82.

Bernauer, Thomas, and Vally Koubi. 2006. On the Interconnectedness of Regulatory Policy and Markets: Lessons from Banking. British Journal of Political Science 36 (3):509-25.

Boardman, Anthony, Ilan Vertinsky, and Diana Whistler. 1997. Using Information Diffusion Models to Estimate the Impacts of Regulatory Events on Publicly Traded Firms. Journal of Public Economics 63 (2):283-300.

Brady, Una, and Robert M. Feinberg. 2000. An Examination of Stock-Price Effects of EU Merger Control Policy. International Journal of Industrial Organization 18 (6):885-900.

Brouard, Sylvain, and Vincent Tiberj. 2006. The French Referendum: The Not So Simple Act of Saying Nay. Political Science \& Politics 29 (2):261-68.

Bulmer, Simon, and Wolfgang Wessels. 1987. The European Council: Decision-making in European Politics. London: Macmillan Press.

Campbell, John Y., Andrew W. Lo, and A. Craig MacKinlay. 1997. The Econometrics of Financial Markets. Princeton, N.J.: Princeton University Press.

Cutler, David M. 1988. Tax Reform and the Stock Market: An Asset Price Approach. American Economic Review 78 (5):1107-17.

DiPietro, William R., Emmanuel Anoruo, and Bansi Sawhney. 2008. The Effect of the Size of the Military on Stock Market Performance in the United States and the UK. Kyklos 61 (1):33-44.

Dreher, Axel, Jan-Egbert Sturm, and James Raymond Vreeland. 2009. Development Aid and International Politics: Does Membership on the UN Security Council Influence World Bank Decisions? Journal of Development Economics 88 (1):1-18.

Elton, Edwin J., Martin J. Gruber, Stephen J. Brown, and William N. Goetzmann. 2007. Modern Portfolio Theory and Investment Analysis. 7th ed. Hoboken, N.J.: John Wiley \& Sons.

European Union. 1999. Presidency Conclusions. Cologne European Council 3 and 4 June 1999. Available at $\langle$ http://ue.eu.int/ueDocs/cms_Data/docs/pressData/en/ec/kolnen.htm〉. Accessed 15 January 2010.

2001. Presidency Conclusions. Göteborg European Council, 15 and 16 June 2001. Available at 〈http://ec.europa.eu/governance/impact/background/docs/goteborg_concl_en.pdf $\rangle$. Accessed 15 January 2010.

2003. A Secure Europe in a Better World-the European Security Strategy. Approved by the European Council held in Brussels on 12 December 2003 and drafted under the responsibilities of 
the EU High Representative Javier Solana. Available at 〈http://www.consilium.europa.eu/uedocs/ cmsUpload/78367.pdf). Accessed 15 January 2010.

Feinberg, Robert M., and Richard K. Harper. 1999. Regime Effects of EU Market Integration Policies on the UK Financial Sector. Review of Industrial Organization 15 (4):357-65.

Fisman, Raymond. 2001. Estimating the Value of Political Connections. American Economic Review 91 (4):1095-102.

Gilligan, Thomas W., and Keith Krehbiel. 1988. Complex rules and congressional outcomes: An event study of energy tax legislation. Journal of Politics 50 (3):625-54.

Grieco, Joseph M. 1988. Anarchy and the Limits of Cooperation: A Realist Critique of the Newest Liberal Institutionalism. International Organization 42 (3):485-507.

Guidolin, Massimo, and Eliana La Ferrara. 2005. The Economic Effects of Violent Conflict: Evidence from Asset Market Reactions. Federal Reserve Bank of St. Louis Working Paper 2005-066A. Available at $\langle$ http://research.stlouisfed.org/wp/2005/2005-066.pdf〉. Accessed 8 January 2010.

2007. Diamonds Are Forever, Wars Are Not: Is Conflict Bad for Private Firms? American Economic Review 97 (5):1978-993.

Hix, Simon. 2008. What's Wrong with the European Union and How to Fix It. London: Polity Press.

Hoffmann, Stanley. 1966. Obstinate and Obsolete? The Fate of the Nation-State and the Case of Western Europe. Daedalus 95 (2):862-915.

Hug, Simon. 2002. Voices of Europe: Citizens, Referendums and European Integration. Lanham, Md.: Rowman \& Littlefield.

Hug, Simon, and Thomas Schulz. 2007. Referendums in the EU's Constitution Building Process. Review of International Organizations 2 (2):177-218.

Kastellec, Jonathan P., and Eduardo Leoni. 2007. Using Graphs Instead of Tables in Political Science. Perspectives on Politics 5 (4):755-71.

König, Thomas, and Mirja Pöter. 2001. Examining the EU Legislative Process. European Union Politics 2 (3):239-351.

Kyung So Im, M. Hashem Pesaran, and Yongcheol Shin. 2003. Testing for Unit Roots in Heterogeneous Panels. Journal of Econometrics 115:53-74.

MacKinlay, A. Craig. 1997. Event Studies in Economics and Finance. Journal of Economic Literature 35 (1):13-39.

Mattila, Mikko, and Tapio Raunio. 2006. Cautious Voters-Supportive Parties; Opinion Congruence Between Voters and Parties on the EU Dimension. European Union Politics 7 (4):427-49.

Mauro, Paolo, Nathan Sussman, and Yishay Yafeh. 2006. Emerging Markets and Financial Globalization Sovereign Bond Spreads in 1870-1913 and Today. Oxford, England: Oxford University Press.

Mearsheimer, John J. 1990. Back to the Future: Instability in Europe After the Cold War. International Security 15 (1):5-56.

. 1994. The False Promise of International Institutions. International Security 19 (3):5-49.

Micco, Alejandro, Ernesto Stein, and Guillermo Ordoñez. 2003. The Currency Union Effect on Trade: Early Evidence from EMU. Economic Policy 18 (37):315-56.

Miller, Merton H., and F. Modigliani. 1961. Dividend, Policy, Growth, and the Valuation of Shares. Journal of Business 34 (4):411-33.

Milward, Alan. 1992. The European Rescue of the Nation State. London: Routledge.

Moravcsik, Andrew. 1993. Preferences and Power in the EC: A Liberal Intergovernmentalist Approach. Journal of Common Market Studies 31 (4):473-524.

1998. The Choice for Europe: Social Purpose and State Power from Rome to Maastricht. Ithaca, N.Y.: Cornell University Press.

Mosley, Layna. 2004. Government Financial Market Relations After EMU: New Currency, New Constraints? European Union Politics 5 (2):181-209.

Nikolaidou, Eftychia. 2008. The Demand for Military Expenditure: Evidence from the EU15. Defence and Peace Economics 19 (4):273-92.

Pantzalis, Christos, David A. Stangeland, and Harry J. Turtle. 2000. Political Elections and the Resolution of Uncertainty. Journal of Banking and Finance 24 (10):1575-604.

Powell, G. Bingham. 2004. The Chain of Responsiveness. Journal of Democracy 15 (4):91-105. 
Putnam, Robert D. 1988. Diplomacy and Domestic Politics: The Logic of Two-Level Games. International Organization 42 (3):427-60.

Sandholz, Wayne, and John Zysman. 1989. 1992: Recasting the European Bargain. World Politics 42 (1):95-128.

Sandler, Todd, and Keith Hartley. 1999. The Political Economy of NATO. Cambridge: Cambridge University Press.

Schelling, Thomas C. 1960. The Strategy of Conflict. Cambridge, Mass.: Harvard University Press.

Schmidt, Manfred G. 1992. Regierungen: Parteipolitische Zusammensetzung. In Lexikon der Politik, Band 3. Die Westlichen Länder, edited by Manfred G. Schmidt, 393-400. Munich, Germany: C.H. Beck.

Schneider, Gerald, and Lars-Erik Cederman. 1994. The Change of Tide in Political Cooperation: A Limited Information Model of European Integration. International Organization 48 (4):633-62.

Schneider, Gerald, and Vera E. Troeger. 2006. War and the World Economy: Stock Market Reactions to International Conflicts, 1990-2000. Journal of Conflict Resolution 50 (5):623-45.

Schneider, Gerald, and Patricia A. Weitsman. 1996. The Punishment Trap: Integration Referendums as Popularity Contests. Comparative Political Studies 28 (4):582-607.

Tufte, Edward R. 1983. The Visual Display of Quantitative Information. Cheshire, Conn.: Graphics Press.

Whitney, Nick. 2008. Re-Energising Europe's Security and Defence Policy. European Council on Foreign Relations Policy Paper. Available at 〈http://ecfr.3cdn.net/678773462b7b6f9893_djm6vu499.pdf〉. Accessed 8 January 2010.

Zimmer, Christina, Gerald Schneider, and Michael Dobbins. 2005. The Contested Council: The Conflict Dimensions of an Intergovernmental EU Institution. Political Studies 53 (2):403-22.

Ziobrowski, Alan J., Ping Cheng, James W. Boyd, and Brigitte J. Ziobrowski. 2004. Abnormal Returns from the Common Stock Investments of the U.S. Senate. Journal of Financial and Quantitative Analysis 39 (4):661-76. 